\title{
De la pena de galeras a las fortificaciones. Uso de reos en los escenarios bélicos en el imperio español
}

\author{
From the penalty of the galleys to the fortifications. \\ The usage of prisoners on the war scenarios of the Spanish Empire \\ Da pena de galeras a fortificações. \\ Uso de prisioneiros em cenários de guerra no império español
}

Lilia Paola Martínez Meléndez ${ }^{1}$ iD

Universidad Nacional Autónoma de México

\begin{abstract}
RESUMEN
La pena de galeras, aplicada en Europa en la antigüedad clásica, el medioevo y el Renacimiento, conoció transformaciones en los siglos posteriores. En esencia, el uso de reos o personas no deseadas de la sociedad para obligarlas a realizar uno de los trabajos más exigentes y peligrosos, fue una práctica que se extendió hasta el siglo XVIII. Los cambios acaecidos con el tiempo generaron modificaciones en la forma en la que se continuó usando reos. Con la llegada de los españoles a América, ya no se castigaba con la pena de galeras; el reo, el marginal, el pobre o el criminal pasaron a ser parte de las filas de trabajadores forzados de las obras públicas, fábricas o minas. Para el siglo XVIII, el utilitarismo punitivo fue una de las herramientas que continuó teniendo vigencia y le permitió a las autoridades y a la Corona española poder llevar a cabo sus planes para la optimización de los recursos de sus colonias.
\end{abstract}

Palabras clave: Caribe; Galeras; Trabajo forzado; Fortificaciones; Mediterráneo; Utilitarismo punitivo.

\begin{abstract}
The penalty of the galleys, widespread in Europe during the Classical Antiquity, Medieval Period and Renaissance transmuted. In essence, the usage of prisoners or the outcasts forcing them into one of the most dangerous and demanding labors was a practice extending until the 18th century. The changes that occured over time generated modifications in the manner in which the usage of prisoners was handled, with the arrival of the Spaniards to America, they were no longer sentenced to the penalty of the galleys, rather, the prisoner, the outcast, the poor, or the criminal became part of the ranks of forced laborers in public works, factories or mines. By the 18th century, punitive utilitarianism was one of the methods that had maintained validity and permitted the authorities and the Spanish Crown to be able to carry out their plans in order to optimize the colonies resources.
\end{abstract}

Keywords: Galleys; forced labor; fortifications; the Mediterranean sea; Caribbean.

\footnotetext{
${ }^{1}$ Maestría en Estudios Latinoamericanos y Estudiante de Doctorado en Estudios Latinoamericanos. Universidad Nacional Autónoma de México.
}

Copyright: (c) 2020. Martínez, L. Este es un artículo de acceso abierto, distribuido bajo los https://creativecommons.org/licenses/bync-sa/4.0/ la cual permite el uso sin restricciones, distribución y reproducción en cualquier medio, siempre y cuando que el original, el autor y la fuente sean acreditados.

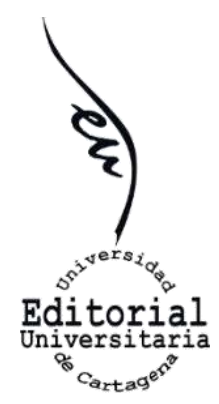




\section{RESUMO}

A penalidade de galeras, aplicada na Europa na antiguidade clássica, na Idade Média e no Renascimento, sofreu transformações nos séculos posteriores. Em essência, o uso de presidiários ou indesejados da sociedade para obrigá-los a realizar um dos trabalhos mais exigentes e perigosos, foi uma prática que se estendeu até o século XVIII. As mudanças ocorridas ao longo do tempo geraram modificações na forma como os presidiários continuaram a ser usados. Com a chegada dos espanhóis à América, o castigo das galés foi interrompido; o recluso, o marginal, o pobre ou o criminoso passaram a fazer parte das fileiras dos trabalhadores forçados em obras públicas, fábricas ou minas. Para o século XVIII, o utilitarismo punitivo foi uma das ferramentas que continuou em vigor e permitiu que as autoridades e a Coroa espanhola realizassem seus planos de otimização dos recursos de suas colônias.

Palavras-chave: Caribe; Galeras; Trabalho forçado; Fortificações; Mediterrâneo; Utilitarismo punitivo.

\section{Transformación de la pena}

El vínculo existente entre las formas de trabajo forzado, esclavo o precariamente pagado con los sistemas penitenciarios ha estado presente en múltiples momentos de la historia y diversas geografías y se ha convertido en un símbolo clásico para representar el castigo a criminales. Durante la modernidad, el Imperio español, usó criminales como mano de obra forzada en sus frentes de trabajo como obras públicas, reforzamiento de las filas de las milicias, como pobladores y habitantes de los presidios ${ }^{2}$. Esta común actividad, viene de una tradición que se pude rastrear desde la utilización de esclavos o prisioneros de guerra en la construcción de las fortalezas romanas, e incluso, desde que se tiene registro de la utilización del hombre por el hombre.

A pesar de que el problema que abarcamos tiene orígenes antiguos, nos centraremos temporalmente durante el denominado periodo de la Ilustración. Este periodo permite entrever el cambio de algunas construcciones políticas, sociales y culturales que habían tenido pervivencia durante siglos y que fueron modificándose con la construcción y puesta en práctica de la filosofía ilustrada y con ella, una serie de discursos que buscaban otorgarle cualidades más razonables a algunas de las actividades humanas, en este caso, en el ejercicio de impartición de justicia. La influencia de las ideas ilustradas llevó, poco a poco, a un cambio en la forma en la que se construían los imaginarios de la sociedad, por ejemplo, intentar demarcar los espacios delegados para las

\footnotetext{
${ }^{2}$ Estos lugares tenían múltiples funciones y objetivos, pero uno de los que más resalta es su carácter de plaza defensiva. Dependiendo de la geografía dónde se establecieran podían ser de defensa en tierra o en mar, fueron enclaves estratégicos para la colonización de regiones consideradas de frontera, pues se encargaban de la defensa de los caminos y los colonos de la zona, ayudaban a controlar el territorio y a mantener al margen a comunidades consideradas hostiles, cómo fue el caso de los presidios del norte de Nueva España. En áreas coseras, los presidios protegían a los convoyes y a los puertos. Estos estaban habitados por tropas fijas, algunos funcionarios como escribanos, capellanes o alcaides y por reos, que pagaban sus condenas en las obras de construcción de estos mismos lugares. Luis Arnal Simón, "Los presidios del norte de África y en la Nueva España", en, Martín F. Ríos Saloma (ed), El mundo de los conquistadores, Ciudad de México, Universidad Nacional Autónoma de México-Instituto de Investigaciones Históricas-Silex Ediciones, 2015, p. 197-198.
} 
prácticas religiosas, las cuales pasaron de un ámbito público a un plano privado, a la construcción de nociones de libertad o individuo; o la estructuración de corpus discursivos en torno a aspectos de la sociedad como el castigo, los criminales o la institución carcelaria, etc. En otras palabras, la creación de lo que posteriormente sería la institucionalidad moderna.

Por otro lado, la redacción, construcción y puesta en marcha de códigos penales fue una de las innovaciones presentadas durante la Ilustración. Desde el siglo XVII y todo el siglo XVIII, en el mundo occidental, se hizo necesario elaborar códigos en los que se definieran claramente qué acciones eran consideradas delitos y las penas que le correspondían, de esa manera los jueces sólo tenían la función de ser aplicadores de la ley y no sus intérpretes, intentando así, separar al juez del verdugo y creando una proto institución judicial. Es así cómo, a través de la redacción de códigos penales se empezó a plantear una separación entre los poderes judiciales y legislativos, que durante mucho tiempo se habían condensado en la imagen del monarca absoluto y que sólo tendrían una efectiva escisión durante los procesos de construcción de los estados nacionales, ya muy entrado el siglo XIX.

De los códigos penales aparecidos durante los siglos XVII y XVIII, uno de los más conocidos fue el Discurso sobre las penas ${ }^{3}$ de Manuel del Lardizábal, en él, el autor intenta recopilar parte del pensamiento ilustrado, aplicado a la regulación de las penas a los criminales con el fin de hacer de estas más justas y equilibradas con respecto a los crímenes señalados. Otro tratado aparecido durante el siglo XVIII fue el escrito por Cesare Beccaria, el cual salió a la luz en 17644; luego de su publicación se suprimió el uso de la tortura en procesos penales en Rusia, Austria y Francia. Este texto sólo recogió ideas que habían estado circulando en un contexto ilustrado y no representaron ninguna innovación para el contexto europeo, pero sí logró condensar en un texto eso elementos que ya se estaban discutiendo en las cortes. Se redactó como un catálogo de los males que aquejaban la justicia como la crueldad en las penas, la arbitrariedad de los jueces, los excesos de los tribunales, el uso de la tortura, la irracionalidad de las leyes, etc., cuestiones que ya habían sido manejadas por los enciclopedistas. Estos códigos fueron propuestos para defender los nacientes derechos del individuo y dejar atrás un periodo que los autores de la época describen como de "barbarie" y desproporcionada administración de justicia.

A pesar de los intentos por normalizar la impartición de justicia, una de las lecciones que dejan los estudios históricos sobre la criminalidad y la marginalidad es que estos intentos de catalogación de las conductas humanas no son una guía ni soporte para entender la realidad de los sociedades y procesos analizados, dado que, en este caso, el ejercicio de impartición de justicia continuaba teniendo un carácter social, o sea, el accionar de las

\footnotetext{
${ }^{3}$ Manuel de Lardizábal y Uribe, Discurso sobre las penas: Contraído a las leyes criminales de España para facilitar su reforma, México, Porrúa, 1982, 293 p.

${ }^{4}$ Cesare Beccaria, De los delitos y las penas, México, Comisión Nacional de Derechos Humanos, 1991,110 p.
} 
autoridades estaba supeditado a los contextos, las particularidades y detalles de cada caso y seguían siendo los jueces y las autoridades locales quienes decidían el devenir de un reo. Estos intentos por catalogar o normalizar el comportamiento humano, por lo general, desean esquematizar la conducta punitiva, pero dejaron de lado un elemento impredecible para un efectivo ejercicio de impartición de justicia: los intereses de los individuos que tenían el poder del ejercicio de justicia o de la sociedad en su conjunto.

Otro objetivo que se puede desglosar de los códigos penales editados durante la Ilustración, fue la intención de desaparecer del espectáculo punitivo, que sólo llegó a eliminarse del ritual de castigo penal a finales del XVIII y principios del siglo XIX.$^{5}$ El suplicio, tenía como esencia, más que castigar al individuo, generar conciencia y pautas de comportamiento sobre las personas que veían este ritual, se buscaba también educar sobre lo justo y lo injusto, lo moral y lo inmoral, todo sobre una base dicotómica de la realidad, que se cimentaba sobre el choque de opuestos y donde el "bien" debía prevalecer sobre el "mal", visión propia de la tradición judeo-cristiana. Dichas penas, además de su función de escarmiento, tenían fines intimidatorios y ejemplarizantes, se educaba a través del miedo, se exponían en público los casos de los criminales como modelos que las personas debían evitar seguir para no contraer un destino penoso y/o doloroso.

El ritual de castigo implicaba la escenificación, de las cuales podemos mencionar la escena compuesta por la imagen del reo montando un asno, obligado a pasearse por las calles de la población, luego de este paseo, era ejecutado en la plaza pública. Esta teatralización del castigo fue desapareciendo, pero la esencia del sistema de justicia seguía manteniendo su carácter pedagógico y utilitarista heredado de la antigüedad.

Con el tiempo, se trasladó el castigo en público a un escenario privado y en el cual se hace uso de noción de la libertad, condensada por la Ilustración y la Revolución francesa, como una aspiración a la cual los seres humanos debían llegar y uno de los valores en los cuales se buscaba el desarrollo de la vida. El castigo entonces, tuvo una ambivalencia, aunque la prioridad ya no era castigar para escarmentar a un grupo o población expectante, se seguía haciendo para reformar y poner a funcionar un engranaje social que, por la aparente descomposición del individuo, estaba afectando el funcionamiento de todo el mecanismo comunitario. Así que, para preservar el orden, se alejaba al ser indeseado de su comunidad y para esto se crearon varias figuras, de las cuales, una de las más usadas fue el destierro.

Se estima que la pena de galeras, fue un castigo heredado de las prácticas de castigo romanas, obteniendo su nombre de los barcos de remos que navegaban el Mediterráneo, sin embargo, sólo se tienen registros oficia les de su impartición a partir del siglo XV, bajo el gobierno de Carlos V. Este castigo

${ }^{5}$ Michel Foucault, Vigilar y castigar. Nacimiento de la prisión, México, Siglo XXI, 1984, p. 17. 
se implementó en un intento por aminorar el impacto corporal de otras penas, como la amputación de miembro, el destierro o la pena capital. Luis de las Heras encontró que los delitos a los que se castigaba con esta pena iban desde hurto, blasfemia, falso testimonio, bigamia, adulterio, sodomía, las personas que huían de la milicia o de las cárceles o vagabundos -en este grupo solías entrar los gitanos, pues su considerada vida errante los hacía merecedores de estigmas que los hacían convertirse en seres no deseados para las poblaciones con las que interactuaban-. ${ }^{6}$

Las galeras, barcos de remo y vela antiguos, eran apropiados para la guerra, por sus características morfológicas eran apropiados para realizar ataques que ameritaban movimientos bélicos cercanos a las costas, pero a la vez eran frágiles, tenían poco calado y eran relativamente lentas. Al ser movidas por los remeros, le restaban importancia al impulso generado por el viento, esto permitía un mayor con en la dirección con la que se quería navegar, así como lo expresa Gregorio Marañón, "el viento es azar y el azar es un mal aliado del que lucha". ${ }^{7}$ Estas embarcaciones fueron regularmente usadas dentro del Mediterráneo en épocas del año de baja intensidad de mareas y casi nunca salían a alta mar ya que no tenían espacio suficiente para el almacenamiento de víveres. Como pena de trabajo forzado, fue un castigo generalizado en los reinos con constas en el Mediterráneo, junto con el presidio en Berbería. Los avances en materia naval y de artillería, sumado a la dificultad para conseguir remeros ocasionó la paulatina desaparición de este tipo de embarcaciones, seguida por su forma de castigo. ${ }^{8}$ Sin embargo, el uso de reos como trabajadores forzados se importó a América, adecuando el uso del trabajo de criminales a las necesidades del nuevo continente.

En este sentido, gracias a una cadena de revoluciones técnicas, el mejoramiento de armas y técnicas de combate, se cambió la forma en la que se organizaban y llevaban a cabo los enfrentamientos bélicos. En el Mediterráneo, con la avanzada turca, los españoles empezaron a modificar la forma en la que se defendían, así que las tildes pasaron a colocarse en la defensa de tierra firme y no en los ataques marítimos. Las cortinas de murallas se levantaban, trasladando así la lógica de la guerra para los españoles del ataque a la defensa.

El castigo en las galeras se convirtió entre los siglos XVI y XVII en el castigo por excelencia del sistema penitenciario peninsular, pues fue una de las estrategias para la lucha contra la delincuencia, por la frecuencia de su imposición, por la variedad de delitos que se castigaban con ella y porque proporcionaba forzados, una fuerza de trabajo fundamental para la política española en el Mediterráneo. ${ }^{9}$, los reos fueron usados para ocupar los lugares

\footnotetext{
${ }^{6}$ José Luis de las Heras Santos, "Los galeotes de los Asturias: la penalidad al servicio de la armada". Historia Social, 6, 1990, pp. 127-128

${ }^{7}$ Gregorio Marañón, "La vida en las galeras en tiempos de Felipe II”. Ars Medica. Revista de Humanidades, 2005, p. 217.

${ }^{8}$ Luis Rodríguez Ramos, "La pena de galeras en la España moderna". Anuario de derecho penal y ciencias penales, Tomo

31, Fasc/Mes 2, Ministerio de Justicia, Secretaría General Técnica; Boletín Oficial del Estado 1978, p. 260.

9 J. L. de las Heras, "Los galeotes de los Asturias", pp. 127-128.
} 
que la población libre no quería ocupar en dichas embarcaciones. Los conflictos que España mantenía con otras potencias en el Mediterráneo generaron la necesidad de aumentar el número de flotas en el mar, esto a su vez, aumentó la necesidad de remeros, ${ }^{10}$ en este sentido, el uso de criminales o personas indeseadas de la sociedad fue el mecanismo para poder mantener a flote estas armas de guerra. En América, los conflictos de España con sus vecinos en Europa continuaron, el requerimiento de hombres para la guerra se mantenía y estos espacios dentro de la milicia, los presidios, las flotas o las fortificaciones fueron ocupados por libres, esclavos y reos.

El ejercicio de impartición de justicia continuó modificándose al llegar a América. Junto con la decadencia del espectáculo punitivo y los castigos corporales que predominaban durante la época pre moderna, la penalidad que se intentaba establecer, a pesar de que se guiaba por los nuevos códigos penales, estaba dominada por las necesidades del Estado monárquico para cubrir destinos en los cuales era difícil fijar hombres libres a cambio de un salario o alguna otra remuneración. Si bien, el castigo dejaba de ser un teatro y el suplicio mermaba, siguió siendo una herramienta útil para los intereses del poder.

En las obras de fortificación, al igual que en las galeras, el cuerpo de trabajadores y remeros tenía diversas procedencias, se le pueden catalogar como grupos heterogéneos, conformado por individuos, cuyas razones por las cuales realizaban el respectivo trabajo iban desde el pago de deudas, el cumplimiento de una pena, hasta la realización de un oficio remunerado. En las galeras, por ejemplo, se clasificaban en buenos boyas, sector conformado por remeros voluntarios, a sueldo y tiempo fijo; esclavos, que podían a su vez tener diversidad de credos y procedencias, en este grupo podían estar cristianos, moriscos, mercaderes, deudores, arráeces (caudillo o jeque árabe) procedentes de capturas durante las campañas de reconquista del territorio del Al Ándalus, pero también eran sujetos obtenidos por medio de compras, donaciones o sentencias; y forzados, que eran en esencia reos, destinados a pagar sus delitos haciendo el trabajo de remo más pesado. ${ }^{11}$

En las obras de fortificaciones el grupo de trabajadores también tenía una procedencia mixta, por ejemplo, en Cartagena de Indias se podía encontrar a capataces asalariados, que por los general eran blancos no mestizos libres aprendices de los ingenieros, los cuales se denominaron como sobrestantes, también encontramos artesanos, peones voluntarios, esclavos del rey y forzados, siendo los esclavos y los forzados el grueso de empleados durante la segunda mitad del siglo XVIII. ${ }^{12}$

\footnotetext{
${ }^{10}$ Pedro Trinidad Fernández, La defensa de la sociedad. Cárcel y delincuencia en España (siglos XVIII-XX), Madrid, Alianza, 1991, p. 21

${ }^{11}$ L. Rodríguez Ramos, "La pena de galeras", p. 262

${ }^{12}$ Lilia Paola Martínez Meléndez, "El trabajador a jornal en Cartagena en la segunda mitad del siglo XVIII", en, Anuario de Historia Regional y de las Fronteras, 25, 2, 2019, pp. 243-274.
} 
Con lo anterior hemos planteado el tema del presente escrito: la utilización de los reos como individuos útiles para los intereses de la Corona en los escenarios bélicos. Este fenómeno puede tener distintos orígenes, los cuales variaron de acuerdo con las circunstancias, pero nos vamos a centrar en uno de ellos, la pena de galeras.

Durante el siglo XVIII, junto a las ideas circundantes sobre derechos naturales del individuo y los tratados sobre las penas, también aparecieron otras ideas que influenciaron y llevaron a la articulación de un sistema penitenciario moderno y de las transformaciones de los sistemas punitivos existentes posteriormente. Según Pedro Trinidad Fernández la desaparición de la tortura, y de paso de las penas que llevaban a la muerte del individuo, por un lado, era un indicador de la transición hacia otra forma de entender la penalidad y el gobierno de los hombres, por otro, era la forma en la que la Corona sacaba ventaja de las nuevas ideas de penalidad en pro de la estabilización de su situación financiera. Para los gobiernos ilustrados un súbdito se convertía en un individuo capaz de generar trabajo y riqueza, era una persona a la cual se debía procurar mantener con vida para aprovechar el beneficio que significaba explotar su fuerza de trabajo; el cuerpo humano, como objeto productivo, adquiere un nuevo valor, aún a pesar de tratarse de un delincuente. Los Borbones entendieron esto, así que intentaron desbloquear todos los aspectos que limitaban el aumento de la producción de sus reinos como el monopolio del comercio, la amortización de la tierra, la fragmentación espacial de la población y sobre todo del comportamiento anti productivo de algunos hombres. ${ }^{13}$

Sobre el comportamiento "anti productivo" de algunos hombres, se creó todo un aparato discursivo que tenía como objetivo la criminalización de los cuerpos poco útiles. Como lo menciona Alejandra Araya, el discurso sobre la vagancia, fue un discurso sobre el trabajo, la utilidad y el orden, que se dirigió principalmente a la población libre, pero tenía una mayor carga en los individuos catalogados como ociosos, vagabundos y malentretenidos. Fue en este siglo dónde se condensa la idea de ociosidad, convirtiendo en un vicio perder el tiempo. ${ }^{14}$

La privación de la libertad como medida de castigo, no representaba mayor beneficio para los intereses de la Corona, que prefirió poner a producir una fuerza laboral que representaba los criminales o sujetos criminalizados. El trabajo forzado en las obras públicas durante el siglo XVIII, adquirió la función que antaño tenía el teatro punitivo, fue tomado como una forma de pedagogía que le enseñaba al individuo y a la comunidad cómo comportarse, a su vez que le permitía al individuo hacer un efectivo aprovechamiento de su tiempo en actividades lícitas.

\footnotetext{
${ }^{13}$ P. Trinidad Fernández, La defensa de la sociedad, p. 58.

${ }^{14}$ Alejandra Araya, Ociosos, vagabundos y malentretenidos en Chile colonial, Santiago de Chile, Dirección de Bibliotecas, Archivos y Museos, Centro de Investigaciones Diego Barros Arana, 1999, p. 36.
} 


\section{El Caribe como el Mediterráneo americano}

Debido a múltiples factores políticos, históricos, económicos e inclusive literarios, el Caribe se ha ganado el apelativo del Mediterráneo de América, al ser un territorio colonizado por europeos peninsulares, la forma con la que se entendió esta nueva geografía fue a través de la realización de analogías de su propia realidad, trasladando así, actividades propias del escenario del Mare Nostrum de los romanos al mar del norte. Han sido varias las personas que han descrito al Caribe como el Mediterráneo americano, son varias las coincidencias estructurales e históricas que permiten hacer paralelismos entre los dos puntos geográficos. Una de ellas es Johanna von Grafentein, quien, en su tesis doctoral publicada bajo el nombre de Nueva España en el Circuncaribe ${ }^{15}$ teoriza sobre las condiciones geográficas y estructurales que hacen de este mar un alter ego del Mediterráneo.

Una de actividades trasladadas fue la guerra y también fue el lugar que albergó la forma modificada de la pena de galeras que en este escrito hemos detectado en el trabajo forzado. En esta geografía, los reos ya no fueron remeros, pero continuaron reforzando las líneas de defensa del imperio gracias a su fuerza de trabajo, como lo hacían años anteriores dentro de estos barcos de guerra, pero esta vez como constructores del sistema de defensa. ${ }^{16}$ Con una tendencia ya identificada en las costas mediterráneas, la actividad bélica española de concentró en la defensa, así que toda la ingeniería de la guerra se trasladó poco a poco del mar a la protección de puertos y tierra firme.

La riqueza de los españoles radicaba en sus posesiones en tierra, pues era el continente quien abastecía de metales, materias primas y pertrechos a las flotas y eso representó una ventaja significativa respecto a los otros reinos europeos. Las rutas comerciales, tan apreciadas en el Mediterráneo pasaron a tener un papel secundario dentro de las relaciones comerciales mundiales, ya que los comerciantes peninsulares y americanos pudieron hacer un puente con oriente a través del Pacífico atravesando América, logrando así crear una red mercantil que algunos autores ha considerado como una primera globalización. ${ }^{17}$

Durante todo el siglo XVI y las primeras dos décadas del siglo XVII, las naciones enemigas de España sólo pudieron ocupar por breve tiempo algunas zonas costeras de América ${ }^{18}$, para ello tuvieron que atacar en reiteradas

\footnotetext{
15 Johanna von Grafenstein, Nueva España en el Circuncaribe, 1779-1808. Revolución, competencia imperial y vínculos inercoloniales, México, Universidad Nacional Autónoma de México-CCYDEL, 1997.

16 AGN. Sección Colonia. Fondo Milicias y Marina, leg 52, f. 26r; Juan Marchena Fernández, La institución militar en Cartagena de Indias en el siglo XVIII, Sevilla, Escuela de altos estudios Hispano-Americanos de Sevilla, 1982, p. 317; Archivo General Simancas (AGS) SGU, leg. 7236,9, fol. 7r; AGS, SGU, leg. 7239,20, fol. 124 v; AGS. SGU, leg. 7240,31, Fol.189 r; AGN-C. Sección Colonia. Fondo Milicias y Marina. leg. 115. Fol. 230.

${ }^{17}$ Mariano Bonialian realiza un detallado análisis de la manera en la que América se inserta dentro de la lógica de comercio mundial, dentro de toda su producción sobre la temática. Ver: Mariano Bonialian, La América española: entre el Pacífico y el Atlántico. Globalización mercantil y economía política. 1580-1840, México, El Colegio de México, 2019,446 p.

${ }^{18} \mathrm{Rafal}$ Reichert, Sobre las olas de un mar plateado. La política defensiva española y el financiamiento militar novohispano en la región del Gran Caribe, 1598-1700, Mérida, Universidad Nacional Autónoma de México-Centro Peninsular en Humanidades y Ciencias Sociales, 2013, p. 9.
} 
ocasiones a las colonias españolas y establecer relaciones mercantiles de facto directamente con algunos americanos. Desde el mismo siglo XVI se tiene registros de ataques de corsarios y piratas, los cuales representaron pérdidas para la Corona, pero también fueron una motivación para fortificar los puertos mayores, principales blancos de los saqueos. Con la crisis de los últimos años de gobierno de los Austrias la geopolítica americana comenzó a tener grandes cambios, la pérdida de territorios antillanos y Jamaica, la inclusión de los ingleses en las costas centroamericanas y el momento crítico de la toma a La Habana en 1762, denotaron que las defensas españolas estaban en extremo debilitadas, volvieran a retomar el foco de la estrategia de control territorial.

Los conflictos que se dieron entre las potencias en el mar Caribe, eran el motivo por el cual España emprendió una campaña para la protección de sus intereses y territorios en América. Como veremos más adelante, en un contexto de tensión, que se fue edificando desde los ataques a las conquistas españolas por parte de holandeses, ingleses y franceses desde el siglo XVI, la Corona tomó medidas tempranas para el cuidado de las riquezas que extraía de América, es por esta razón que se fortifican los puertos por los cuales salían los metales preciosos y productos agrícolas del Nuevo Mundo, se dio punto de partida para un sistema de navegación escoltado, mejor conocido como sistema de flotas, que fue útil hasta el siglo XVII y primeras décadas del siglo XVIII, y se formaron las bases de lo que sería un ejército especializado.

Con una tendencia a la desaparición desde el siglo XV, las galeras no llegaron a ser un medio de transporte en América, tampoco lograron ser una herramienta bélica de provecho, para el siglo XV y XVI, ya se habían convertido en un medio de transporte y bélico insostenible, a pesar de que como pena, se encontraba en un punto de auge, resultaba costoso mantenerlas dado que un año de mantenimiento de una galera equivalía al valor de su propia construcción, además del entrenamiento, aprovisionamiento del equipo y dinero necesario, también resultaba muy difícil reunirlas para realizar ataques en conjunto; por su forma esbelta, no contaban con espacio suficiente para cargar por sí misma los pertrechos que requería su tripulación, por eso por lo general, eran acompañadas por otras embarcaciones encargadas de su abastecimiento. ${ }^{19}$ Para los viajes a través del Atlántico se prefirió el uso de los robustos galeones, un poco más lentos, pero un tanto más seguros.

La forma en la que se reclutaban los galeotes para los remos es muy similar a manera en la que se criminalizaba la vagancia en América durante el siglo XVIII. Los gitanos, eternos parias de la sociedad europea occidental, por ejemplo, fueron reclutados para ser remeros sólo porque hacían falta manos para impulsar las galeras. ${ }^{20}$ En América se trasladó la necesidad de crear un "otro" y eso fue a través de los discursos de criminalidad como la ya mencionada criminalización de la vagancia.

\footnotetext{
${ }^{19}$ Fernand Braudel, El Mediterráneo y el mundo del Mediterráneo en la época de Felipe II, tomo II, México, Fondo de Cultura Económica, 2019, p. 248, 252.

${ }^{20}$ F. Braudel, El Mediterráneo y el mundo, p. 253
} 
Se pueden establecer algunos paralelismos entre la forma en la que se castigaba en el Mediterráneo y cómo se castigó en el Caribe. Ya hemos anotado que tanto los galeotes del Mediterráneo como los trabajadores forzados de las fortificaciones, eran en gran medida criminales, por otro lado, el tiempo de duración de la pena galeras había tenido un tipo de concordato, luego de una disposición del Concilio de Trento la duración máxima de la pena no podía superar los 10 años, así mismo se han encontrado registros en las comunicaciones entre autoridades, donde el mayor tiempo asignado para una pena de trabajo forzado en fortalezas es también de 10 años. Los cuadros 1 y 2 evidencian el tiempo máximo de duración de la pena de trabajos forzados, aunque en algunas ocasiones se imponía un destierro perpetuo, esto se debe a las particularidades del caso condenado, es decir, era una excepción a la norma.

Cuadro 1: Relación dónde se notifica el número creciente de delitos, 1752

\begin{tabular}{|c|c|c|c|}
\hline Nombre & Delito & Condena & Tiempo \\
\hline $\begin{array}{l}\text { Hipólito } \\
\text { de Ortega }\end{array}$ & $\begin{array}{l}\text { Por varias heridas por } \\
\text { sentencia de visita y } \\
\text { revista de la Real } \\
\text { Audiencia pronunciadas en } \\
17 \text { de febrero y } 14 \text { de } \\
\text { octubre de } 1752\end{array}$ & $\begin{array}{l}\text { Destierro en las fábricas de } \\
\text { Cartagena }\end{array}$ & 10 años \\
\hline $\begin{array}{l}\text { Laurean } \\
\text { Limas }\end{array}$ & $\begin{array}{l}\text { Por la muerte que ejecutó } \\
\text { en Juan Ballesteros } 28 \text { de } \\
\text { abril y ocho de agosto de } \\
1752\end{array}$ & $\begin{array}{l}\text { Destierro en las fábricas de } \\
\text { Cartagena a ración y sin } \\
\text { sueldo }\end{array}$ & 6 años \\
\hline $\begin{array}{l}\text { Felipe } \\
\text { Pérez }\end{array}$ & $\begin{array}{l}\text { Por el delito de abeyliato } \\
\text { en } 13 \text { de mayo y } 11 \text { de } \\
\text { agosto de } 1752\end{array}$ & $\begin{array}{l}\text { Destierro en las fábricas de } \\
\text { Cartagena, } 200 \text { azotes a } \\
\text { ración y sin sueldo }\end{array}$ & 8 años \\
\hline $\begin{array}{l}\text { Manuel } \\
\text { Gamboa }\end{array}$ & $\begin{array}{l}\text { Por el homicidio de Jacinta } \\
\text { Metalero, su suegra }\end{array}$ & $\begin{array}{l}\text { Destierro a las fábricas de } \\
\text { Cartagena a ración y sin } \\
\text { sueldo, y que cumplidos } \\
\text { no pueda salir de ella sin } \\
\text { licencia de esta real } \\
\text { audiencia }\end{array}$ & 10 años \\
\hline $\begin{array}{l}\text { Ignacio } \\
\text { Hernández }\end{array}$ & $\begin{array}{l}\text { Por hurtos, } 1 \text { de agosto y } \\
13 \text { de octubre de } 1752\end{array}$ & $\begin{array}{l}\text { Destierro en las fábricas de } \\
\text { Cartagena a ración y sin } \\
\text { sueldo }\end{array}$ & 4 años \\
\hline $\begin{array}{l}\text { Francisco } \\
\text { Reyes }\end{array}$ & $\begin{array}{l}\text { Por la muerte de Salvador } \\
\text { de Otálora, } 18 \text { de } \\
\text { septiembre y } 14 \text { de octubre } \\
\text { de } 1752\end{array}$ & $\begin{array}{l}\text { Destierro en las fábricas de } \\
\text { Cartagena a ración y sin } \\
\text { sueldo }\end{array}$ & 8 años \\
\hline $\begin{array}{l}\text { Francisco } \\
\text { Espinoza }\end{array}$ & $\begin{array}{l}\text { Por la muerte que dio a } \\
\text { Juan Salvador de Moya, } 6 \\
\text { de noviembre y } 7 \text { de } \\
\text { diciembre de } 1752\end{array}$ & $\begin{array}{l}\text { Destierro, } 200 \text { azotes a } \\
\text { ración y sin sueldo en las } \\
\text { fábricas de Cartagena }\end{array}$ & 8 años \\
\hline $\begin{array}{l}\text { Juan del } \\
\text { Castillo }\end{array}$ & $\begin{array}{l}\text { No identificado, sentencia } \\
\text { pronunciada el } 9 \text { de } \\
\text { noviembre de } 1752\end{array}$ & $\begin{array}{l}\text { Destierro en las fábricas de } \\
\text { Cartagena a ración y sin } \\
\text { sueldo }\end{array}$ & 6 años \\
\hline
\end{tabular}




\begin{tabular}{|c|c|c|c|}
\hline $\begin{array}{l}\text { Laurean } \\
\text { Castillo }\end{array}$ & $\begin{array}{l}\text { No identificado, es el } \\
\text { mismo delito anterior, } 9 \text { de } \\
\text { noviembre de } 1752\end{array}$ & $\begin{array}{l}\text { Destierro en las fábricas de } \\
\text { Cartagena a ración y sin } \\
\text { sueldo }\end{array}$ & 8 años \\
\hline $\begin{array}{l}\text { Joseph de } \\
\text { Aldana }\end{array}$ & $\begin{array}{l}\text { Por hurtos, sentencia } \\
\text { pronunciada por la justicia } \\
\text { ordinaria de esta ciudad el } \\
21 \text { de julio }\end{array}$ & $\begin{array}{l}50 \text { azotes en la reja de la } \\
\text { cárcel y destierro en las } \\
\text { fábricas de Cartagena }\end{array}$ & 4 años \\
\hline $\begin{array}{l}\text { Juan } \\
\text { Peláez }\end{array}$ & $\begin{array}{l}\text { Por muerte de Agustín de } \\
\text { Tolosa, sentencia } \\
\text { pronunciada en } 28 \text { de } \\
\text { noviembre de } 1752\end{array}$ & $\begin{array}{l}\text { Destierro en las fábricas de } \\
\text { Cartagena a ración y sin } \\
\text { sueldo }\end{array}$ & 10 años \\
\hline $\begin{array}{l}\text { Thomás } \\
\text { Delgadillo }\end{array}$ & $\begin{array}{l}\text { Por la muerte de Isidro } \\
\text { Mochoa, lo condena la real } \\
\text { audiencia el } 14 \text { de } \\
\text { septiembre de } 1752\end{array}$ & $\begin{array}{l}\text { Destierro en las fábricas de } \\
\text { Cartagena a ración y sin } \\
\text { sueldo y que cumplido el } \\
\text { tiempo no salgo sin la } \\
\text { autorización de la real } \\
\text { audiencia. }\end{array}$ & 10 años \\
\hline $\begin{array}{l}\text { Carlos } \\
\text { Ximenes }\end{array}$ & $\begin{array}{l}\text { Por hurtos, haciendo } \\
\text { justicia el } 20 \text { de octubre de } \\
1752\end{array}$ & $\begin{array}{l}\text { Destierro en las fábricas de } \\
\text { Cartagena a ración y sin } \\
\text { sueldo }\end{array}$ & 6 años \\
\hline $\begin{array}{l}\text { Nicolás de } \\
\text { Amaia }\end{array}$ & $\begin{array}{l}\text { Por hurtos, sentencia } \\
\text { pronunciada por la justicia } \\
\text { ordinaria el } 3 \text { de } \\
\text { noviembre de } 1752\end{array}$ & $\begin{array}{l}\text { Destierro en las fábricas de } \\
\text { Cartagena a ración y sin } \\
\text { sueldo }\end{array}$ & 8 años \\
\hline $\begin{array}{l}\text { Francisco } \\
\text { Xavier } \\
\text { Rodríguez }\end{array}$ & $\begin{array}{l}\text { Delito no identificado, es } \\
\text { el mismo que estas } \\
\text { buscando. } 21 \text { de octubre, } \\
\text { condena de la real } \\
\text { audiencia }\end{array}$ & $\begin{array}{l}\text { Destierro en las fábricas de } \\
\text { Cartagena a ración y sin } \\
\text { sueldo }\end{array}$ & 4 años \\
\hline $\begin{array}{l}\text { Francisco } \\
\text { de Roxas }\end{array}$ & $\begin{array}{l}\text { Por el delito de homicidio, } \\
\text { sentencia dada por la real } \\
\text { audiencia octubre de } 1752\end{array}$ & $\begin{array}{l}\text { Destierro en las fábricas de } \\
\text { Cartagena a ración y sin } \\
\text { sueldo }\end{array}$ & 4 años \\
\hline $\begin{array}{l}\text { Lorenzo } \\
\text { Roxas }\end{array}$ & $\begin{array}{l}\text { Por varios hurtos, } \\
\text { sentencia de la Real } \\
\text { Audiencia } 1 \text { de agosto de } 3 \\
\text { de octubre de } 1752\end{array}$ & $\begin{array}{l}\text { Destierro en las fábricas de } \\
\text { Cartagena }\end{array}$ & 6 años \\
\hline $\begin{array}{l}\text { Gregorio } \\
\text { Bilches }\end{array}$ & $\begin{array}{l}\text { Por abayjato (busca bien } \\
\text { ese delito), sentencia de la } \\
\text { real audiencia }\end{array}$ & $\begin{array}{l}\text { Destierro en las Fábricas } \\
\text { de Cartagena a ración y sin } \\
\text { sueldo }\end{array}$ & 2 años \\
\hline $\begin{array}{l}\text { Agustín } \\
\text { del Río }\end{array}$ & $\begin{array}{l}\text { Por el homicidio de } \\
\text { Alonso Magallón, } \\
\text { sentencia de la Real } \\
\text { audiencia el } 30 \text { de agosto y } \\
17 \text { de octubre de } 1752\end{array}$ & $\begin{array}{l}\text { Destierro en las fábricas de } \\
\text { Cartagena a ración y sin } \\
\text { sueldo }\end{array}$ & 10 años \\
\hline $\begin{array}{l}\text { Juan } \\
\text { Cañón }\end{array}$ & $\begin{array}{l}\text { Por homicidios de Juan } \\
\text { Calderón, sentencia de la } \\
\text { justicia ordinaria el } 30 \text { de } \\
\text { octubre de } 1752\end{array}$ & $\begin{array}{l}\text { Se le condenó a servir en } \\
\text { las fábricas de Cartagena a } \\
\text { ración y sin sueldo por } \\
\text { toda su vida, a } 200 \text { azotes }\end{array}$ & $\begin{array}{l}10 \text { años } \\
\text { a ración } \\
\text { y sin } \\
\text { sueldo }\end{array}$ \\
\hline
\end{tabular}




\begin{tabular}{|l|l|l|l|}
\hline $\begin{array}{l}\text { Antonio } \\
\text { Padilla }\end{array}$ & $\begin{array}{l}\text { Por hurtos, 21 de octubre } \\
\text { de } 1752\end{array}$ & $\begin{array}{l}\text { Destierro en las fábricas de } \\
\text { Cartagena a ración y sin } \\
\text { sueldo, 200 azotes }\end{array}$ & 8 años \\
\hline $\begin{array}{l}\text { Joseph } \\
\text { Quiroga }\end{array}$ & $\begin{array}{l}\text { Por el delito de abejato y el } \\
\text { homicidio de Pedro Pérez, } \\
\text { sentencia de la justicia } \\
\text { ordinaria, 14 de enero de } \\
1752\end{array}$ & $\begin{array}{l}\text { Destierro en las fábricas de } \\
\text { Cartagena a ración y sin } \\
\text { sueldo }\end{array}$ & 6 años \\
\hline $\begin{array}{l}\text { Agustín } \\
\text { Suarez }\end{array}$ & $\begin{array}{l}\text { Por abejiato, sentencia de } \\
16 \text { de octubre de 1752 }\end{array}$ & $\begin{array}{l}\text { Destierro en las fábricas de } \\
\text { Cartagena a ración y sin } \\
\text { sueldo }\end{array}$ & 6 años \\
\hline $\begin{array}{l}\text { Santiago } \\
\text { de } \\
\text { Apolinar }\end{array}$ & $\begin{array}{l}\text { Por el homicidio de Juan } \\
\text { Pérez, indio tributario, } \\
\text { sentencia de la Real } \\
\text { audiencia del 14 de } \\
\text { septiembre }\end{array}$ & $\begin{array}{l}\text { Destierro en las fábricas de } \\
\text { Cartagena a ración y sin } \\
\text { sueldo }\end{array}$ & 10 años \\
\hline $\begin{array}{l}\text { Cristóbal } \\
\text { Lasante }\end{array}$ & $\begin{array}{l}\text { Por abeijiato, sentencia de } \\
\text { la Real Audiencia } 16 \text { de } \\
\text { octubre de 1752 }\end{array}$ & $\begin{array}{l}\text { Destierro en las fábricas de } \\
\text { Cartagena a ración y sin } \\
\text { sueldo }\end{array}$ & 4 años \\
\hline
\end{tabular}

Fuentes: Elaboración de la autora con base en AGN, Sección Colonia, fondo Juicios Criminales, leg. 87 , doc. 20 , fs. $458-467$

Cuadro 2: Relación de reos enviados desde Santafé a Cartagena, 1754

\begin{tabular}{|l|l|l|l|}
\hline Nombre & \multicolumn{1}{|c|}{ Delito } & \multicolumn{1}{|c|}{ Condena } & Tiempo \\
\hline $\begin{array}{l}\text { Esteban } \\
\text { Buitrago }\end{array}$ & $\begin{array}{l}\text { Herida que dio a Juan } \\
\text { Joseph de Torrez }\end{array}$ & $\begin{array}{l}\text { Fábricas de Cartagena a } \\
\text { ración diaria de comida y } \\
\text { sin sueldo }\end{array}$ & 4 años, \\
\hline $\begin{array}{l}\text { Luis } \\
\text { Hernández los crueles y atroces } \\
\text { golpes que dio a María } \\
\text { Bello, a que se diese le } \\
\text { sobrevino la muerte 29 } \\
\text { de marzo de y 15 de } \\
\text { junio del año pasado, } \\
1753\end{array}$ & $\begin{array}{l}\text { Servir en las fábricas de la } \\
\text { ciudad de Cartagena a } \\
\text { ración y sin sueldo, con } \\
\text { declaración que cumplido } \\
\text { dicho término no salga de } \\
\text { ellas con expresa orden de } \\
\text { esta real audiencia }\end{array}$ & $\begin{array}{l}10 \text { años } 200 \\
\text { azotes. }\end{array}$ \\
\hline $\begin{array}{l}\text { Pascual } \\
\text { Sotero }\end{array}$ & $\begin{array}{l}\text { Por el homicidio de } \\
\text { Pascual Benito, en 29 de } \\
\text { marzo y 2 de mayo de } \\
1753\end{array}$ & $\begin{array}{l}\text { Destierro en las fábricas de } \\
\text { Cartagena a ración y sin } \\
\text { sueldo }\end{array}$ & 6 años \\
\hline $\begin{array}{l}\text { Custodio } \\
\text { Paima }\end{array}$ & $\begin{array}{l}\text { Por heridas que hizo a } \\
\text { Juan Bacilio de los } \\
\text { Reyes, 10 de julio y doce } \\
12 \text { de septiembre de 1753 }\end{array}$ & $\begin{array}{l}\text { Destierro en las fábricas de } \\
\text { Cartagena, para que sirva } \\
\text { en ellas a ración y sin } \\
\text { sueldo }\end{array}$ & 5 años \\
\hline $\begin{array}{l}\text { Francisco } \\
\text { López de } \\
\text { Herrera }\end{array}$ & $\begin{array}{l}\text { Abeigrato por } \\
\text { pertenencias, 28 de } \\
\text { noviembre de 1753 }\end{array}$ & $\begin{array}{l}\text { Destierro en las fábricas de } \\
\text { Cartagena a ración y sin } \\
\text { sueldo }\end{array}$ & 2 años \\
\hline $\begin{array}{l}\text { Manuel } \\
\text { Rodríguez } \\
\text { Carbajal }\end{array}$ & $\begin{array}{l}\text { Por el homicidio de } \\
\text { Manuel Vázquez }\end{array}$ & $\begin{array}{l}\text { Cartagena a ración y sin } \\
\text { sueldo }\end{array}$ & $\begin{array}{l}10 \text { y años } 200 \\
\text { azotes }\end{array}$ \\
\hline
\end{tabular}




\begin{tabular}{|c|c|c|c|}
\hline $\begin{array}{l}\text { Manuel } \\
\text { Aponte }\end{array}$ & $\begin{array}{l}\text { Hurtos y complicidad en } \\
\text { la muerte de Joseph } \\
\text { Grimaldos } 30 \text { de marzo } \\
\text { de } 1754\end{array}$ & $\begin{array}{l}\text { Destierro en las fábricas de } \\
\text { Cartagena a ración y sin } \\
\text { sueldo, sentencia el } 19 \text { de } \\
\text { julio de } 1754\end{array}$ & $\begin{array}{l}4 \text { años y } \\
200 \\
\text { azotes }\end{array}$ \\
\hline $\begin{array}{l}\text { Naresso } \\
\text { Pardo y de } \\
\text { Alonzo } \\
\text { Pardo }\end{array}$ & $\begin{array}{l}\text { Reutencias hechas a la } \\
\text { justicia }\end{array}$ & $\begin{array}{l}\text { Destierro en la fábricas de } \\
\text { Cartagena a ración y sin } \\
\text { sueldo }\end{array}$ & 4 años \\
\hline $\begin{array}{l}\text { Matías } \\
\text { Moreno de } \\
\text { Acosta }\end{array}$ & $\begin{array}{l}\text { Homicidio de Joseph } \\
\text { Gramaldos y heridas a } \\
\text { Antonia González y otras } \\
\text { heridas que causó a } \\
\text { Javier Daso, a Matías de } \\
\text { Bohasa y Salvador } \\
\text { Inacanja. } 17 \text { de } \\
\text { noviembre y } 22 \text { de } \\
\text { diciembre de } 1751\end{array}$ & $\begin{array}{l}\text { A que por todos los días de } \\
\text { su vida sirva a ración y sin } \\
\text { sueldo en las fábricas de la } \\
\text { ciudad de Cartagena en } \\
\text { calidad de desterrado }\end{array}$ & $\begin{array}{l}\text { Cadena } \\
\text { perpetua } \\
\text { y a } 200 \\
\text { azotes }\end{array}$ \\
\hline $\begin{array}{l}\text { Gaspar de } \\
\text { quesada }\end{array}$ & $\begin{array}{l}\text { Por haber herido a } \\
\text { Manuela Hurtado en } \\
\text { primero de noviembre de } \\
1750\end{array}$ & $\begin{array}{l}\text { Destierro en las fábricas de } \\
\text { Cartagena a ración y sin } \\
\text { sueldo. Por haberse fugado } \\
\text { de las fábricas sin haber } \\
\text { cumplido se le aumenta la } \\
\text { condena }\end{array}$ & $\begin{array}{l}2 \text { años y } \\
200 \\
\text { azotes } \\
10 \text { años }\end{array}$ \\
\hline $\begin{array}{l}\text { Francisco } \\
\text { Javier } \\
\text { Bautista } \\
\end{array}$ & \multirow{3}{*}{$\begin{array}{l}\text { Por ser personas } \\
\text { inquietas y revoltosas por } \\
\text { decreto de } 7 \text { de agosto de } \\
1754\end{array}$} & \multirow{3}{*}{$\begin{array}{l}\text { Destierro en las fábricas de } \\
\text { Cartagena a ración y sin } \\
\text { sueldo }\end{array}$} & \multirow{3}{*}{5 años } \\
\hline $\begin{array}{l}\text { Ignacio } \\
\text { Gonzalez }\end{array}$ & & & \\
\hline $\begin{array}{l}\text { Joseph } \\
\text { Dionisio } \\
\text { Moreno } \\
\end{array}$ & & & \\
\hline $\begin{array}{l}\text { Bernardo } \\
\text { de Cruz }\end{array}$ & $\begin{array}{l}\text { Por el homicidio que } \\
\text { ejecutó en Felipe de la } \\
\text { Barrera }\end{array}$ & $\begin{array}{l}\text { Destierro en las fábricas de } \\
\text { Cartagena a ración y sin } \\
\text { sueldo }\end{array}$ & $\begin{array}{l}6 \text { años y } \\
200 \\
\text { azotes }\end{array}$ \\
\hline $\begin{array}{l}\text { Marcos } \\
\text { Severino }\end{array}$ & Por hurto & $\begin{array}{l}\text { Destierro en las fábricas de } \\
\text { Cartagena a ración y sin } \\
\text { sueldo }\end{array}$ & 6 años \\
\hline $\begin{array}{l}\text { Diego } \\
\text { Farías }\end{array}$ & Por hurtos & $\begin{array}{l}\text { Destierro en las fábricas de } \\
\text { Cartagena a ración y sin } \\
\text { sueldo y que sea sacado a } \\
\text { la vergüenza pública }\end{array}$ & 4 años \\
\hline $\begin{array}{l}\text { Daniel } \\
\text { Cáceres }\end{array}$ & $\begin{array}{l}\text { Por el homicidio de Dian } \\
\text { Hurtado } 1753\end{array}$ & $\begin{array}{l}\text { Destierro en las fábricas de } \\
\text { Cartagena a ración y sin } \\
\text { sueldo }\end{array}$ & 6 años \\
\hline $\begin{array}{l}\text { Raymundo } \\
\text { Canas }\end{array}$ & $\begin{array}{l}\text { Por la extracción de unos } \\
\text { doblones que le confió } \\
\text { don Manuel Montes para } \\
\text { llevar a la villa de Honda } \\
1754\end{array}$ & $\begin{array}{l}\text { Destierro en las fábricas de } \\
\text { Cartagena a ración y sin } \\
\text { sueldo }\end{array}$ & 2 años \\
\hline
\end{tabular}




\begin{tabular}{|l|l|l|l|}
\hline Agustín \\
Banbagun & $\begin{array}{l}\text { Por el fraticidio } \\
\text { efectuado en Francisco } \\
\text { Bambaguay 1753 }\end{array}$ & $\begin{array}{l}\text { Destierro en las fábricas de } \\
\text { Cartagena a ración y sin } \\
\text { sueldo. Como tiene una } \\
\text { herida en la hernia, se hace } \\
\text { poco hábil para el trabajo } \\
\text { recio. Como no puede } \\
\text { trabajar, se le condena a } \\
\text { permanecer los 4 años en la } \\
\text { plaza }\end{array}$ & 4 años \\
\hline $\begin{array}{l}\text { José de la } \\
\text { Parra }\end{array}$ & $\begin{array}{l}\text { Por el homicidio de } \\
\text { Lucas Ruiz 1754 }\end{array}$ & $\begin{array}{l}\text { Destierro en las fábricas de } \\
\text { Cartagena a ración y sin } \\
\text { sueldo }\end{array}$ & 4 años \\
\hline $\begin{array}{l}\text { Juan de } \\
\text { Sevilla }\end{array}$ & $\begin{array}{l}\text { Por el homicidio de } \\
\text { Francisco Camacho }\end{array}$ & $\begin{array}{l}\text { Destierro perpetuo en las } \\
\text { fábricas de Cartagena a } \\
\text { ración y sin sueldo }\end{array}$ & $\begin{array}{l}\text { Perpetuo } \\
\text { y 200 } \\
\text { azotes }\end{array}$ \\
\hline $\begin{array}{l}\text { Baltazar } \\
\text { Miranda }\end{array}$ & $\begin{array}{l}\text { Por la renuencia hecha a } \\
\text { la vusticia por sentencias } \\
\text { pronunciadas 10 de julio } \\
\text { y 12 de agosto de 1754 }\end{array}$ & $\begin{array}{l}\text { Destierro en las fábricas de } \\
\text { Cartagena a ración y sin } \\
\text { sueldo }\end{array}$ & $\begin{array}{l}\text { Perpetuo } \\
\text { y 200 } \\
\text { azotes }\end{array}$ \\
\hline $\begin{array}{l}\text { Joseph } \\
\text { Pacheco }\end{array}$ & $\begin{array}{l}\text { Por haber dado unos } \\
\text { golpes y heridas a } \\
\text { Bernardo Pacheco, su } \\
\text { padre }\end{array}$ & $\begin{array}{l}\text { Destierro en las fábricas de } \\
\text { la ciudad de Cartagena y a } \\
\text { que sea sacado a la } \\
\text { vergüenza pública }\end{array}$ & 4 años \\
\hline
\end{tabular}

Fuentes: Elaboración de la autora con base en AGN, Sección Colonia, fondo Juicios Criminales, leg. 80, doc. 3, fs.154-163.

La información contenida en estas tablas, además de mostrar el tiempo de las condenas, también ilustra el tipo de delitos por los cuales fueron condenados. Un análisis más detallado de estos datos puede ser trabajados en investigaciones futuras, donde se resuelvan interrogantes como la pertinencia del castigo respecto al crimen cometido o el tipo de crímenes condenados en el contexto de guerra que ya se ha ilustrado.

Tanto en la pena de galeras como la condena de trabajos forzados, los cuerpos condenados se veían a merced del verdugo o sistema judicial. En cuanto al castigo en sí, sólo hubo un cambio de geografías y escenarios, en vista de que la esencia utilitarista del castigo seguía estando latente. En el Caribe, un mar en continuos conflictos de intereses, la fuerza de los hombres condenados ya no se necesitaría para darle impulso a los barcos de guerra, sino para la edificación de las armas de defensa.

\section{Guerra en el Caribe: estrategia de combate, del ataque a la defensa}

Durante el desarrollo del siglo XVIII, se dio un cambio de poderes entre las potencias que disputaban el control en el mar Caribe, hegemonías tradicionales como la española se vieron amenazadas por el creciente fortalecimiento naval y político de Inglaterra, Francia y Holanda. Los choques de poder fueron una constante, tanto en un escenario mundial -atlántico- 
mediterráneo- como regional. La confrontación geopolítica convirtió al Caribe en uno de los mayores centros de interés de los países en contienda, ya que era el paso para el intercambio mercantil de las materias primas y productos manufacturados elaborados en las colonias españolas y el Mundo Antiguo. Ya para el siglo XVIII, "Inglaterra afianza su poder marítimo, Francia redefine su posición frente al resto de las monarquías y, entre tanto, España se propone recuperar, bajo la nueva casa reinante, el poder que tuvo en Europa y América durante el siglo XVI". ${ }^{21}$ La guerra, fue el lenguaje de interacción y el motor de gran parte de la actividad comercial, civil, militar y naviera durante este periodo.

A partir de la llegada de Colón a América, las pugnas de interés políticos dejaron de darse en el plano mediterráneo y pasaron a realizarse, sin dejar de lado el territorio del Antiguo Continente, a un nuevo escenario multinacional: el mar Caribe. Encierra este mar, hasta cierto punto, la historia de los imperios occidentales, convirtiéndose también en un núcleo estratégico de rivalidad, en donde los imperios se reinventaron constantemente, y pasaron de ser enemigos a aliados, según las circunstancias. ${ }^{22}$ Como campo de batalla, las potencias en pugna debían asegurar escenarios que les permitieran tener un accionar bélico y un margen de ventaja con respecto a su adversario. España, como mayor detento de espacio marítimo en el Caribe, optó por la defensa de las zonas costeras, asegurando sus puertos y protegiendo las rutas de sus navíos, como el sistema de flotas. Luego de los primeros ataques y saqueos que comenzaron a darse desde el siglo XVI, la Corona tuvo que planear estrategias para evitar que estos saqueos continuaran efectuándose en los principales puertos y evitar el asalto de los barcos en su trayecto desde y hacia España. Sólo hasta 1561 se ordenó por medio de una Real Cédula, la organización de un sistema de flotas y galeones con el fin de proteger la navegación de los buques de carga. Las rutas de las flotas zarpaban una vez al año, entre fines de marzo y principios de abril, ${ }^{23}$ generando un circuito comercial conocido por los habitantes de la época, las ferias.

Al igual que guerras anteriores, las tensiones que reinaban en Europa después de la Guerra de Sucesión se trasladaron a América, y fue justamente el mar Caribe, uno de los escenarios de confrontación. Los intentos de saqueo de los territorios españoles en el nuevo continente fueron los detonantes de las alertas de la Corona hacia la protección, en primera instancia, de sus puertos mayores (La Habana, Veracruz y San Juan de Ulúa, Cartagena, San Juan, Acapulco), de sus rutas de navegación y de sus territorios tierra adentro. Las lógicas de poder y de interés por el control del mar ocasionaron la formación de un ambiente tenso, el cual se había configurado desde el mismo momento en que se descubrieron las tierras americanas.

\footnotetext{
${ }^{21}$ Carmen Blázquez Domínguez, Breve historia de Veracruz, México, El Colegio de México-Fideicomiso Historia de las Américas-Fondo de Cultura Económica, 2000, p. 95.

${ }^{22}$ Consuelo Naranjo, Historia mínima de las Antillas hispánicas y británicas, México, El Colegio de México, 2014, p. 23.

${ }^{23}$ R. Romano, Mecanismo y elementos, p. 274
} 
A diferencia de las acciones implementadas por los gobiernos monárquicos anteriores a la dinastía borbona, a su llegada, ésta se propuso implantar un régimen de control que hasta el momento no se había experimentado en América. Durante buena parte del periodo virreinal, la administración española no se preocupó en las mismas dimensiones por la salvaguarda de la totalidad de sus posesiones, hecho que llevó a la pérdida de control sobre determinados lugares. Los nuevos ocupantes de territorios detentados por España, se apoyaron en la tesis de Mare Liberum de Hugo Grocio, publicada en 1609, la cual argumentaba que, a pesar de la existencia del tratado de Tordesillas, el sólo hecho de haber descubierto un territorio y no habitarlo era un motivo para pérdida de soberanía sobre el mismo. ${ }^{24}$

Durante el siglo XVII se efectuaron ataques que desencadenaron en pérdidas para los intereses españoles. Pese a los primeros intentos por fortificar algunos puertos en el Caribe, durante los reinados de Felipe IV (1621-1665) y Carlos II (1665-1700) no se pudieron evitar las ocupaciones de las Antillas Menores, como San Cristóbal, Martinica, Guadalupe y San Martín. ${ }^{25}$ Estos territorios cayeron con cierta facilidad dado que España no les había atribuido mucha importancia al parecer islas desiertas. En general, las economías de las Antillas españolas no eran suficientemente fuertes como para mantener plazas militares con sus propios recursos y el envío de situados se reservaba para los puertos mayores como Cartagena o La Habana. Fue por ello por lo que se diseñó el sistema de situado para solventar la carencia de capital de territorios que no podían generar suficientes recursos propios y poder así mantener una permanencia estatal y militar en ellos ${ }^{26}$. Sin embargo, esta medida llegó luego de la pérdida de los territorios en las Antillas Menores, se enfocó luego, en zonas de mayor interés productivo y estratégico, como Cuba, Puerto Rico y Santo Domingo, islas de mayor tamaño y potencial productivo.

El establecimiento ya permanente de las potencias enemigas de España en el Caribe significó una preocupación latente para el Imperio. Tanto Francia como Inglaterra se habían apoderado de lugares clave para el tráfico naviero en el mar, lo que les permitió no sólo fortalecer su capacidad bélica o logística, sino también ampliar su margen de acción comercial. Los puntos perdidos fungían como centros de abastecimiento a los barcos que seguían su camino hacia Europa. Los ingleses, al tomar Jamaica, convirtieron la isla en poco tiempo en un centro ganadero, esclavista y de operaciones de corsarios y filibusteros, la colonización de la isla llegó al punto de convertirla en el principal enclave inglés en el Caribe. ${ }^{27}$

Algunas amenazas de invasión se dieron también en tierra firme, en las costas de la Mosquita en Centroamérica y en la zona del río Wallix en los extremos de surorientales de la península de Yucatán. Lo que si podemos afirmar es

\footnotetext{
${ }^{24}$ C. Naranjo, Historia mínima, p. 24.

${ }^{25}$ Rafal Reichert, "La pérdida de la isla de Jamaica por la Corona española y los intentos de recuperarla durante los años

1655-1660". Ulúa. Revista de Historia, 7, 14, 2009, p. 10.

${ }^{26}$ R. Reichert, Sobre las olas, p. 11.

${ }^{27}$ C. Naranjo, Historia mínima, p. 55.
} 
que cada uno de esos ataques y continuas amenazas de saqueo sirvieron para que se diera un proceso de militarización, reforzamiento de la seguridad de los puertos y la reactivación de las acciones para la reconstrucción y edificación de fortificaciones, lo que conllevaba a una necesidad incesante de mano de obra. ${ }^{28}$ Por sus pérdidas en el mar, se ha tejido un mito en torno a la incapacidad española para defender y mantener en pie un imperio de las magnitudes de la época, sin embargo, pese a los continuos intentos de ataques y saqueos, se continuaron manteniendo los territorios bajo el dominio de la Corona y unificados bajo un sólo monarca.

El tráfico comercial en el Caribe permitió tener la presencia de múltiples actores, tanto a los integrantes del comercio monopólico como a los contrabandistas y, a pesar, de que los segundos iban ganando espacios paulatinamente no impidió que en la segunda mitad del siglo XVIII se presentara un incremento en el comercio entre España y las colonias en América, el control y los incentivos ejercidos por los Borbones permitió un proceso de activación de las relaciones comerciales entre el Viejo y el Nuevo Mundo. Fue un periodo de tránsito de las ideas a través de los libros que se imprimían en cantidades que no habían tenido precedentes, de manufacturas, de personas y funcionarios, en síntesis, se presenció una intensificación comercial de circulación de múltiples artilugios entre las potencias europeas y las colonias. ${ }^{29}$

\section{Defensa en tierra firme}

Ante las exigencias defensivas generadas por la guerra, se requirió de importantes cantidades de capital, tanto monetario como humano. El Imperio español fue un imperio que creció relativamente a la defensiva, si bien los primeros años de colonización de América fueron violentos, los años subsiguientes debía encargarse de mantener todo el territorio que logró ostentar, más no emprender campañas bélicas para arrebatar tierras a otras naciones europeas. En simultáneo, mantenía conflictos dentro de las fronteras internas debido a la resistencia puesta por algunos pueblos nativos que se negaban a incorporarse al orden colonial y a ceder sus territorios. En este sentido, la Corona protegió sus fronteras exteriores y atacó en sus límites internos. Debía estar preparada para los eventuales intentos que saqueo o ataque y a las alianzas que los grupos indígenas realizaban con sus enemigos europeos.

La cantidad de ataques que enfrentó el Imperio lo debilitaron desde el punto de vista económico, ya que las finanzas no alcanzaban para pagar los altos costos que ello conllevaba ${ }^{30}$, dado que toda acción bélica es un derroche de

\footnotetext{
28 Jorge L. Lizardi Pollock, "Presidios, presidiarios y desertores: los desterrados de Nueva España", en, Johanna von Grafenstein, El Caribe en los intereses imperiales, 1750-1815, México, Instituto de Investigaciones Dr. José María Luis Mora, 2000, p. 21.

${ }^{29}$ Cristina Gómez Álvarez, "Comercio y comerciantes del libro en la Carrera de Indias: Cádiz-Veracruz, 1750-1778”, Historia Mexicana, LVII,3, 2008, pp. 622-623.

${ }^{30}$ C. Naranjo, Historia mínima, p. 25.
} 
recursos, aunque sólo sean maniobras de defensa. Como vimos, el proceso para el reforzamiento del sistema defensivo de los puertos en el Caribe inició desde el siglo XVI, sin embargo, estas primeras edificaciones demostraron ser insuficientes para enfrentar las incursiones enemigas. Con el siglo XVIII y el cambio de dinastía, también se cambió la manera en la que se defendían los intereses peninsulares. La decadencia de las flotas fue un síntoma que la defensa empezaría a concentrarse en la defensa de tierra firme; el programa de revitalización de las fortificaciones emprendido por Felipe V contemplaba la adición de nuevos elementos al sistema, el establecimiento de unidades militares y la creación de astilleros para la construcción de barcos de guerra. ${ }^{31}$ Todos estos esfuerzos representaron un desgaste monetario y humano, el cual era enfrentado por las cajas de las mismas entidades territoriales americanas y por las personas que habitaban este territorio. De los virreinatos salieron hombres para asumir esa fuerza de trabajo y recursos monetarios para hacerle frente a la creciente demanda. El dinero circulante salía especialmente de los virreinatos más acaudalados como Nueva España o Perú y los brazos que se usaron para construir las fortalezas eran reclutados de casi todos los puntos del continente.

En Misericordia, Antonio García de León hace una narración del proceso de captura y traslado de una cuerda de apaches capturados por el ejército español en la frontera norte de Nueva España. Estos indios, considerados como rebeldes, se enjuiciaban y tenían como destino el trabajo forzado en las fortificaciones de Veracruz. ${ }^{32}$ Caso similar, pero de reclutamiento de vagos, documentó Enriqueta Quiroz para el caso de Chile, este grupo de personas fueron usadas para completar el grupo de trabajadores para la construcción de la Casa de la Monera. ${ }^{33} \mathrm{Y}$, como otro ejemplo, algunos de los reos que llegaban a la ciudad de Cartagena, provenían de la Real Audiencia de Santafe, que se encargaba del enjuiciamiento de las personas criminalizadas del virreinato de la Nueva Granada.

Luego de perder el control de los puntos en el Caribe nombrados anteriormente, la Corona reconocía con mayor certeza la importancia de los territorios de ultramar. Parte de los esfuerzos se encaminaron en fortalecer el aparato estatal en América, enviando funcionarios preparados, aumentando el sistema de impuestos o militarizando algunas plazas. A pesar de las pérdidas ocasionadas en años anteriores, los ojos de la Corona permanecieron en los centros más grandes del mar, Cuba, Santo Domingo, Puerto Rico, Florida y la isla de Trinidad, las posesiones en tierra firme se aseguraron con cordones de piedra y las islas con flotas militares. La intención era conservar los territorios que aún les pertenecían, frenar la avanzada enemiga y recuperar el poderío que se les había arrebatado, hecho que no implicaba necesariamente

\footnotetext{
${ }^{31}$ C. Blázquez Domínguez, Breve historia de Veracruz, pp. 120-121.

${ }^{32}$ Antonio García de León, Misericordia. El destino trágico de una collera de apaches en la Nueva España, México, Fondo de Cultura Económica, 2017, p. 215.

${ }^{33}$ Enriqueta Quiroz, "Salarios y condiciones de vida en Santiago de Chile, 1785-1805: a través del caso de la construcción de la Casa de la Moneda", en, Diana Bonnett y Enriqueta Quiroz, Condiciones de vida y de trabajo en la América colonial: legislación, prácticas laborales y sistemas salariales, Bogotá, Universidad de los Andes-CESO, 2009.
} 
la recuperación de los territorios, pero si el control sobre el mar y las rutas de navegación.

Habiendo superado algunos ataques de piratas y corsarios durante los siglos XVI y XVII, la Corona había mantenido bajas las alertas de ataques o posibles invasiones. Pero en el siglo XVIII un ataque despertó las alarmas de la Corona sobre sus posesiones en el Caribe, la invasión inglesa a La Habana en 1762, un ataque que preocupó a las autoridades al nivel de llevar a replantearse los planes de defensa que habían estado vigentes hasta ese entonces. Este episodio fue un parteaguas en materia de estrategia defensiva y militar, lo que ocasionó que la atención de la Corona se centrara en la defensa del Caribe, lo cual conllevaría a la destinación de parte considerable de los recursos nuevamente a la protección del territorio.

En este momento, fueron San Juan de Puerto Rico, Cartagena de Indias, Portobelo, La Habana y San Juan de Ulúa los lugares escogidos para ser refortificados. A causa de su posición geográfica, estos puntos, representaban un problema dicotómico, eran al tiempo fortaleza y debilidad para el Imperio. Las llamadas "Llaves de las Indias" fueron entonces el depósito de un andamiaje que estaba encaminado a proveer seguridad a los tesoros que guardaban tras sus puertas, ${ }^{34}$ pero al mismo tiempo de convertían en presas de fácil identificación para los ataques enemigos.

Otras medidas tomadas por los gobiernos Borbones fueron la acentuación de la centralización administrativa del territorio y de las finanzas y, por consiguiente, el fortalecimiento de las finanzas locales. Por otro lado, en los lugares donde aún era considerable en número de la población indígena, se mejoró la fiscalización del tributo, al incrementarse la base tributaria y se estableció la monetarización del mismo, ${ }^{35}$ es decir, ya no se pagaba en especie el tributo, sino con dinero. La Corona deseaba un imperio que económicamente tuviera un sustento lo suficientemente sólido y una maquinaria bélica superior para poder garantizar la seguridad y protección de sus riquezas. ${ }^{36}$

\section{El trabajo forzado, una solución a la crisis en la recaudación fiscal}

Lo turbulento que resultó la segunda mitad del siglo XVIII para el Caribe no sólo fue en un plano político, sino también fiscal. Las guerras que había sostenido España socavaban las entrañas de sus finanzas, dejando en muchas ocasiones sin los fondos suficientes a los virreinatos que abastecían a la Corona de plata, Nueva España y Perú. Los esfuerzos emprendidos por las reformas borbónicas, que apuntaban hacia un cambio en la administración del territorio, mayor control de la población, aumento de los impuestos y el

\footnotetext{
${ }^{34}$ R. Reichert, Sobre las olas, p. 9.

${ }^{35}$ C. Blázquez Domínguez, Breve historia de Veracruz, p. 107.

${ }^{36}$ J. L. Lizardi Pollock, "Presidios, presidiarios y desertores", p. 20.
} 
fomento de las actividades productivas, ${ }^{37}$ no impidieron que la crisis en el sistema de recaudación fiscal llegara y que la quiebra afectara los planes que se venían gestando, especialmente en materia de seguridad, en lo que respecta al proceso de construcción de fortificaciones o aumento de la milicia.

Carlos Marichal sostiene que la clásica idea que se había formado en torno a la debilidad de las finanzas del Siglo de las luces no es tan cierta; según esta postura, el XVIII fue una centuria de prosperidad, pero también de grandes gastos fiscales. Marichal apunta que esta idea de una crisis debe ser matizada, ya que los estudios en los que se basó dieron indicios de un panorama de importantes recaudos de impuestos y producción de las provincias, pero en medio de un contexto de guerra. Sustentándose en investigaciones realizadas en los últimos cuarenta años, afirma que, frente a la aparente riqueza que se percibía en el virreinato de Nueva España, de trasfondo subsistía un proceso de endeudamiento que debilitaba la estabilidad fiscal del virreinato y de los territorios que estaban bajo su jurisdicción, Cuba y Puerto Rico, para ser más exactos. Dicha crisis afectó tanto las finanzas, hasta el punto de llevarlo a la quiebra. ${ }^{38}$ Las necesidades de la época demandaban grandes gastos en materia militar, a pesar de la poca liquides, se persistía en el mantenimiento de grandes ejércitos y flotas en las guerras que sostuvo España durante el siglo XVIII y primeros años del siglo XIX, además de los mismos gastos que generaba la edificación de los cordones amurallados. ${ }^{39}$

La crisis en las finanzas provocó que el proceso de endeudamiento se intensificara, esta misma situación llevó a la población a la marginación y el hambre, reflejándose en un aparente aumento del bandolerismo, del alcoholismo, los robos o las formas de violencia urbana. ${ }^{40} \mathrm{El}$ aumento en la recaudación de impuestos no iba encaminado al mejoramiento de las condiciones de vida de los habitantes del Imperio, sino en la sobrevivencia de la institución militar. ${ }^{41} \mathrm{El}$ incremento en la criminalidad fue un problema que preocupaba a la administración colonial y su solución terminó por hacerle frente a dos problemáticas que aquejaban a los demás territorios españoles en América; el primero era depurar la sociedad de individuos que afectaran el orden y las buenas costumbres de una comunidad, al condenarlos a pagar sus penas en el destierro o el presidio, se sacaba de la comunidad a los individuos indeseados; y el segundo problema fue la subsanación del déficit de mano de obra en las obras de fortificación, al usar a los criminales desterrados como trabajadores forzados en estas.

A pesar de los recursos monetarios que se enviaban con frecuencia a los centros de trabajo, la crisis de la Corona se vio reflejada en las

\footnotetext{
${ }^{37}$ C. Blázquez Domínguez, Breve historia de Veracruz, p. 96.

${ }^{38}$ Carlos Marichal, La bancarrota del virreinato: Nueva España y las finanzas del imperio español, 1780-1810, México, El Colegio de México-Fondo de Cultura Económica, 1999, pp. 15-17.

${ }^{39}$ Carlos Marichal y Johanna von Grafenstein, El secreto del Imperio español. Los situados coloniales en el siglo XVIII, México, El Colegio de México-CEH-Instituto Mora, p. 9-31.

40 J. L Lizardi Pollock, "Presidios, presidiarios y desertores", p. 20.

${ }^{41}$ Adolfo Meisel Roca, "Reformas borbónicas y presión fiscal 1761-1880", en, Adolfo Meisel Roca y María Teresa Ramírez,

La economía colonial de la Nueva Granada, Bogotá, Fondo de Cultura Económica-Banco de la República, 2015 , p. 249.
} 
comunicaciones de los ingenieros argumentando la falta de recursos y materiales para la correcta ejecución de los castigos a los criminales y el traslado de estos hacia sus lugares de reclusión y la persistente falta de mano de obra en las construcciones. ${ }^{42}$

En el caso de Nueva Granada, los ingresos que se generaban para la Corona en los últimos años de dominación "alcanzaron en promedio la suma de 2,4 millones de pesos, unos 770.000 pesos aportados por los estancos de tabaco y aguardiente. Los otros productos estancados -como la sal, la pólvora y los naipes- completarían un monto de 861.000 pesos (33,4\% del recaudo) al final de la dominación española, constituyendo el rubro más importante de los recursos acopiados por la Corona". ${ }^{43} \mathrm{La}$ intención de los Borbones era aumentar la recaudación, pero sin desacelerar la producción es por ello que se redujo sustancialmente el impuesto a la extracción minera, del 5\% inicial que se tenía que tributar, se pasó a un $3 \% .{ }^{44}$

En suma, en un contexto de guerra, los recursos humanos y monetarios eran una necesidad constante. La presión fiscal y la enorme demanda de recursos, el mencionado supuesto aumento de la criminalidad y un afán administrativo por depurar a la sociedad de individuos indeseables, configuraron el escenario en donde las acciones tomadas por los tribunales de justicia de América se sirvieron para atemorizar a los delincuentes con la idea del destierro o los trabajos forzados en obras públicas, ${ }^{45}$ para de esta manera poder contar con una presencia significativa de mano de obra forzada en las obras de fortificación y con ello economizar los gastos en defensa.

En este sentido, obligar a los criminales a cumplir sus condenas realizando trabajos forzados en las obras de fortificación y otros escenarios creados por la guerra, fue una medida que contribuyó a saldar varios problemas de la Corona simultáneamente. El primero, los niveles de criminalidad y el control de la población haciendo uso del miedo, y el segundo, saldar los faltantes de mano de obra de menor costo en todo tipo de obras públicas que se pudieran presentar, las cuales son para nuestro caso, las obras de fortificación de los puertos del Caribe.

\section{A manera de conclusión}

Durante el siglo XVIII la Corona española bajo el domino Borbón, emprendió una serie de maniobras con miras a recuperar el poderío que antaño había ostentado en territorio americano. Luego de haber perdido importantes territorios en el mar de las Antillas y conocer las avanzadas de los reinos enemigos en tierras continentales, comprendió que necesitaba reforzar su presencia en sus posesiones de ultramar. Bajo el influjo de la Ilustración, los

${ }^{42}$ AGN, Criminales-Juicios, leg. 129, doc. 36, fol. 899-900.

${ }^{43}$ Salomón Kalmanovitz, "El PIB de la Nueva Granada en 1800: auge colonial, estancamiento republicano", en, Revista de Economía Institucional, 8, 15, 2008, p. 163.

${ }^{44}$ S. Kalmanovitz, "El PIB de la Nueva Granada”, p. 163; A. Meisel Roca, "Reformas borbónicas”,pp. $249,252$.

${ }^{45}$ J. L. Lizardi Pollock, "Presidios, presidiarios y desertores", p. 21. 
deseos de hacer aún más próspero el Imperio se materializaron cambios en los ámbitos políticos, económicos, sociales y militares.

Uno de los puntos de concentración de la política borbona fue la protección de los puertos mayores y la profesionalización de su ejército, en vista de los constantes ataques a los que se veían enfrentadas las colonias. Para ello, se reanudaron los trabajos en las fortificaciones de los puertos mayores y se ampliaron las filas de las milicias. Esto conllevó a un aumento en el gasto militar el cual no era sólo monetario, sino que también requería de un aumento en el número de sujetos que iban no sólo a los escuadrones del ejército, sino también, quienes se destinaban a las obras de construcción de las fortalezas.

La construcción de estos fuertes representó la activación del mundo laboral de las plazas, fueron empleados centenares de hombres libres quienes fueron asalariados como los artesanos, los capataces o los peones. Pero también se emplearon esclavos del rey y reos, que a diferencia del grupo anterior no recibían una paga por su trabajo. Fueron los reos, los sujetos que personificaron parte de la esencia de la política y la filosofía borbona, maximizar los recursos del imperio al tiempo que hacían productivos los cuerpos.

Como lo sostiene Braudel, la guerra es un gasto y un derroche, el cual, al ser asumido conlleva a la pérdida de recursos tanto monetarios como humanos. Para España, haberse convertido en un imperio de dimensiones globales le representó, si bien, un garante de riqueza, también el hecho de adquirir la responsabilidad de sostenerse como un imperio de tales envergaduras. En estas páginas hemos hablado sobre uno de los mecanismos que usó la Corona para poder proteger su territorio, mecanismo que a su vez le permitió sopesar los gastos que conlleva una guerra, el utilitarismo punitivo.

La presencia de reos en las obras de fortificación, como mutación de la pena de galeras, denota una clara intención por tarde de las autoridades por obtener provecho de los sujetos criminalizados y excluidos de la sociedad. Desde las luchas sostenidas en el mar interior europeo, hasta el traslado de la guerra al Caribe, el otro indeseado, el gitano, el vago, el criminal, será quién tome el lugar del trabajador forzado, del remero. Fueron esos sujetos que se vieron obligados a trabajar de "sol a sol" para justificar su existencia.

\section{Bibliografía}

\section{Fuentes primarias}

Archivo General de la Nación. Sección Colonia. Fondo Criminales-Juicios.

Archivo General de la Nación. Sección Colonia. Fondo Milicias y Marina.

Archivo General de Simancas. Secretaría de Estado y del Despacho de Guerra. 
Beccaria, Cesare, De los delitos y las penas, México, Comisión Nacional de Derechos Humanos, 1991.

Lardizábal y Uribe, Manuel de, Discurso sobre las penas: Contraído a las leyes criminales de España para facilitar su reforma, México, Porrúa, 1982.

\section{Fuentes secundarias}

Araya, Alejandra, Ociosos, vagabundos y malentretenidos en Chile colonial, Santiago de Chile, Dirección de Bibliotecas, Archivos y Museos, Centro de Investigaciones Diego Barros Arana, 1999.

Arnal, Luis Simón, "Los presidios del norte de África y en la Nueva España", en, Martín F. Ríos Saloma (ed), El mundo de los conquistadores, México, Universidad Nacional Autónoma de México-Instituto de Investigaciones Históricas-Silex Ediciones, 2015, p. 197-226.

Blázquez Domínguez, Carmen, Breve historia de Veracruz, Ciudad de México, El Colegio de México-Fideicomiso Historia de las Américas-Fondo de Cultura Económica, 2000.

Bonialian, Mariano, La América española: entre el Pacífico y el Atlántico. Globalización mercantil y economía política. 1580-1840, México, El Colegio de México, 2019.

Foucault, Michel, Vigilar y castigar. Nacimiento de la prisión, México, Siglo XXI, 1984.

García de León Antonio, Misericordia. El destino trágico de una collera de apaches en la Nueva España, México, Fondo de Cultura Económica, 2017, p. 215.

Grafenstein Johanna von, Nueva España en el Circuncaribe, 1779-1808. Revolución, competencia imperial y vínculos intercoloniales, México, Universidad Nacional Autónoma de México-CCYDEL, 1997.

Grafenstein, Johanna von, El Caribe en los intereses imperiales, 1750-1815, México, Instituto de Investigaciones Dr. José María Luis Mora, 2000.

Heras Santos José Luis de las, "Los galeotes de los Asturias: la penalidad al servicio de la armada", Historia Social, 6, 1990, pp. 127-128

Marañón Gregorio, "La vida en las galeras en tiempos de Felipe II", Ars Medica. Revista de Humanidades, 2005.

Marichal, Carlos, La bancarrota del virreinato: Nueva España y las finanzas del imperio español, 1780-1810, México, El Colegio de México-Fondo de Cultura Económica, 1999.

Marichal Carlos y Grafenstein Johanna von, El secreto del Imperio español. Los situados coloniales en el siglo XVIII, México, El Colegio de México-CEHInstituto Mora, p. 9-31. 
Martínez Meléndez Lilia Paola, "El trabajador a jornal en Cartagena en la segunda mitad del siglo XVIII", en, Anuario de Historia Regional y de las Fronteras, 25, 2, 2019, 243-274.

Meisel Roca, Adolfo y Ramírez, María Teresa (eds.), La economía colonial de la Nueva Granada, Bogotá, Fondo de Cultura Económica-Banco de la República, 2015.

Naranjo, Consuelo, Historia mínima de las Antillas hispánicas y británicas, México, El Colegio de México, 2014.

Quiroz Enriqueta, "Salarios y condiciones de vida en Santiago de Chile, 1785-1805: a través del caso de la construcción de la Casa de la Moneda", en Diana Bonnett y Enriqueta Quiroz, Condiciones de vida y de trabajo en la América colonial: legislación, prácticas laborales y sistemas salariales, Bogotá, Universidad de los Andes-CESO, 2009.

Reichert, Rafal, "La pérdida de la isla de Jamaica por la Corona española y los intentos de recuperarla durante los años 1655-1660", en, Ulúa. Revista de Historia, Sociedad y Cultura, Universidad Veracruzana, Xalapa, Año 7/Núm. 14 Julio-diciembre de 2009, p. 9-33.

Reichert, Rafal, Sobre las olas de un mar plateado. La política defensiva española y el financiamiento militar novohispano en la región del Gran Caribe, 1598-1700, Mérida, Universidad Nacional Autónoma de México-Centro Peninsular en Humanidades y Ciencias Sociales, 2013.

Reichert, Rafal y AA VV, "Piratas, situados y naufragios. Financiamiento Militar novohispano para los presidios Del gran Caribe, siglos XVI y XVII", en, Discursos históricos, literarios y culturales desde el sur de México y Centroamérica, Universidad de Ciencias y Artes de Chiapas-Centro de Estudios Superiores de México y Centroamérica, México, 2015, p. 281.

Rodríguez Ramos, Luis, "La pena de galeras en la España moderna”, en, Anuario de Derecho Penal y Ciencias Penales, 31, 1978, 259-276.

Romano, Ruggiero, Mecanismo y elementos del sistema económico colonial americano, siglos XVI-XVIII, Ciudad de México, Fondo de Cultura EconómicaEl Colegio de México, 2004.

Trinidad Fernández, Pedro, La defensa de la sociedad. Cárcel y delincuencia en España (siglos XVIII-XX), Madrid, Alianza, 1991, p. 360. 